\title{
ASSERTIVE BEHAVIOR AND ITS APPLICATION BY ISLAMIC EDUCATION TEACHER IN THE ASSESSMENT OF STUDENT LEARNING OUTCOMES
}

\author{
Husna Nur Huuda \\ Study Program of Islamic Education, Faculty of Tarbiyah and Teacher Training \\ State Islamic University of Sunan Kalijaga \\ Email: huhuhusna@gmail.com
}

Website: http://jurnal.uin-antasari.ac.id/index.php/itjik

Received: 23 November 2019; Accepted: 10 February 2020; Published: 29 June 2020

\begin{abstract}
This study aimed to find out the application of assertive behavior by the teacher of Islamic Education Studies and to determine the results of the application in improving students' achievement in SMPN 1 Godean. This research is a descriptive qualitative field research. The data collection methods were observation, documentation and interview. Furthermore, the data analysis were using the model of Miles and Huberman which are data reduction, data presentation, and drawing conclusions. The results of this study indicated that the behavior of Islamic Education Studies teacher is able to express the feelings well, sometimes expressed thoughts and beliefs openly and able to maintain the personal rights. Based on those 3 components and 4 characteristics of assertive behavior, the teacher applied 2 components and 3 characteristics of assertive behavior. Thus, the results of the application of Islamic Education Studies teacher's assertive behavior made students in learning the subject were more contented and enthusiastic so that this has an effect on students' achievement, as evidenced by the students' high scores on final test which have an average value above the Minimum Standard Criteria (KKM).
\end{abstract}

Keywords : assertive behavior; teacher of Islamic Education Studies; students' achievement.

\section{INTRODUCTION}

In general, educators have major responsibility to educate as well as to influence a person's development. For education is a process, there will certainly be various educators who influence the development of students (Helmawati, 2016: 147). One of them is the teacher, who becomes the spearhead in the learning process, since the teachers interacts directly with students in the classroom. Their existence plays a significant role in making students understand and comprehend the delivered-subjects. Moreover, schools as educational institutions need teachers who are not only as instructors teaching certain subjects to their students, but also as educators who provide students with insights about ethics, life survival skills, morals, empathy and creation (Fathurrohman \& Aa, 2012: 13).

Therefore teachers must have behaviors that can be emulated and respected by their students, besides teachers must also have the behavior or ability to express rights, thoughts, feelings and beliefs directly, honestly, respectfully and not interfere with the rights of others. Such behavior is called as assertive behavior.

According to Robert Alberti \& Michael Emmons: Assertive behavior promotes equality in human relationship, which allows us to act in our own interests without undue anxiety, to express feelings honestly and comfortably, to implement our 
personal rights without denying the rights of others (Alberti \& Michael, 2002: 41).

In addition, according to Herbert Fensterhein \& Jean Bear, assertive is the activity or attitude of someone in expressing opinions and actual expressions without fear as well as able to communicate with others smoothly (Fensterhein \& Jean, 1980: 67). Assertiveness is included in emotional intelligence. Even more, Oxford English Dictionary literally defines emotion as "every activity or processing of thoughts, feelings, desires; every mental state that is great and overflowing. Emotion refers to a feeling and specific thoughts, or a biological and psychological state, and a series of tendencies to act (Goleman, 2007: 411). Emotional intelligence is an extended ability which a person has in motivating themselves, having self-awareness, resilience in the face of failure, controlling emotions and adjourning satisfaction, further, having social skills (Uno, 2006: 68).

Steven J. Stein and Howard E. Book, quoted by Hamzah B Uno explained the Reuven Bar-On findings which was encapsulated emotional intelligences and they are divided into five broad areas or domains. The five areas are:

1. The intrapersonal realm covers five subdivisions or scales, namely selfawareness, assertiveness, independence, self-esteem and self-actualization.

2. The interpersonal realm consists of three scales, namely empathy, social responsibility and interpersonal relationship.

3. Self-adjustment realm includes three scales, namely reality testing, flexible attitudes and problem solving.

4. Stress controlling realm has two scales, namely endurance to bear stress and impulse control.

5. General mood realm also has two scales, namely optimism and happiness (Uno, 2006: 76).

Based on the five areas or domains that have been described by Steven J. Stein and Howard E. Book above, it can be seen that assertive behavior is included in emotional intelligence and existed in intrapersonal area or domain. For this reason, the intrapersonal realm is related people's ability to recognize and have selfcontrol.

There are several studies related to assertive behavior, including the Journal written by Selfi, a Guidance and Counseling teacher at SMPN 1 Sungguminasa 2017 entitled "Application of Assertive Training Techniques in Reducing Negative Conformity towards Peer Groups in Middle School." This study aims to determine (1) the description of the application on assertive training techniques in reducing negative conformity towards peer groups, (2) the description of negative conformity of students before and after being given assertive training techniques, (3) the application of assertive training techniques reduces negative conformity to peer groups. This research is a quantitative study using true experimental design with pretest-posttest control group design. The results showed that (1) Implementation of assertive training techniques to reduce negative conformity to peer groups is carried out in accordance with procedures that have been designed through 5 meetings, (2) Negative conformity towards peer groups before the application of assertive training techniques is in the high category. But after applying the assertive training technique, its result is in the low category, (3) Application of assertve training techniques in reducing negative conformity towards peer groups in SMP Negeri 1 Sungguminasa. This means that students who are given the application of assertive training show a decrease in the level of negative conformity to peer groups (Selfi, 2017: 153). If the preceding discussed-research is more about the assertive behavior of the students, then in this latter study what is discussed is more on the assertive behavior of the teacher. Furthermore, the journal written by Syahrul 
Abidin, a student of the Faculty of Social Sciences at UIN North Sumatra Medan in 2017, entitled "Teacher Communication Strategies in Improving Learning Achievement." This study aimed to discuss a matter of teacher communication strategies towards students in improving student learning achievement. This research is a qualitative research, in which the researcher is the key of instrument. The results showed that the teacher's communication strategies in improving student achievement at school was more on rewarding the students' actions, yet in fact teachers often misinterpreted this strategy, the teacher only takes that in the form of punishment given to students who were guilty, even though the rewards should also be given to the excellent students in the form of prizes, praise and others. Communication strategies undertaken by teachers in improving student achievements in school may run well if parents are able to corporate their roles in terms of interactive communication (Abidin, 2017: 116). Previously, the earlier research discusses the teacher's strategies in increasing students' achievement, however, in this study it discusses the application of teacher's assertive behavior in improving learning achievement.

Due to the data in field which are still found many cases of teacher violence against students, it is necessary to examine how the behavior of a teacher, which is expected to behave assertively in accordance with the components and characteristics of assertive behavior theory, since the teacher behaves assertively in teaching would certainly affect student achievement. In addition, learning achievement is the mastery of knowledge or skills developed by the subject, usually indicated by the test scores or numbers given by the teacher. Furthermore, if the teacher fulfills the elements along with the characteristics of assertive behavior extendedly then it will definitely improve student learning achievement, but it might also turn out otherwise, to find out how many elements and characteristics of Islamic Education teacher's assertive behavior to improve student achievement. This approach result can only be known after the researcher finishes in-depth observation. This research was conducted at SMPN 1 Godean, as the research location. This study is a qualitative study in which the researcher pays fully attention to the teacher's behavior and reinforces it with interviews with colleagues who are close or not so close to the Islamic Education teacher, along with students who are taught by. Particularly, the research has two major focuses. First, the researcher looks at the symptoms that appear in a teacher by referring to the assertive behavior theory, so that it can be seen what the components and characteristics that exist in a teacher. Secondly, by seeing the assertive behavior that exists in a teacher, whether or not, it can boost the student achievement for having better scores.

Thus, the researcher intended to further examine "Assertive Behavior and Its Application by Islamic Education Teachers in Improving Student Achievement at State Junior High School (SMP) 1 Godean of Sleman". The details about the description of the research process on this issue will be described below.

\section{RESEARCH METHOD}

According to its type of research, this is a field research. This research is a qualitative descriptive study which aims to explain social phenomena or events. Overall, the subjects in this qualitative descriptive study were: an Islamic Education Teacher in SMPN 1 Godean, twenty students from different classes, four colleagues or teachers who are more familiar with the main subject and the headmaster. Data collection used several techniques which are observation, interviews, and documentation. The concept of data analysis in this study used 
the steps proposed by Milles and Hiberman, namely: data reduction, data display, data verification.

\section{FINDING AND DISCUSSION}

\section{A. The Application of Assertive Behavior Implemented by the Islamic Education Teacher of SMPN 1 Godean of Sleman}

Assertive behavior is the activity or attitude of a person expressing opinions and actual expressions without having fear and able to communicate with others smoothly. Basically, everyone has the right to express opinions freely, however, it means not as freely as there are no rules, yet freely to express opinions well, politely, firmly, and do not deny the rights of others or denigrate, drop, and hurt other people. In the fact that this assertive behavior was sparked by Robert Alberti \& Michael Emmons in his book Your Perfect Right: Assertiveness and Equality in Your Life.

Next, to find out how the implementation of assertive behavior by the teacher of Islamic Education in SMPN 1 Godean of Sleman, the researcher would explore the opinions of school principal and teachers as well as students regarding assertive behavior of mentioned-teacher through questions containing components of assertive behavior.

1. The principal, of SMPN 1 Godean said that the Islamic Education teacher implemented almost perfect components of assertive behavior, wrapped in the following conclusions : 1. The teacher was able to express the feelings well. 2. Expressing beliefs and thoughts openly at certain times which the teacher need. 3. Expressing ordinary personal rights or this can be articulated that it is not always done, which means there is still a closure that he does not want to say by having a sense of anxiety that was occured. 4. The Islamic Education teacher has never been seen angry. 5. In interacting with others Islamic Education teachers, the mentioned-teacher need time and process in approaching their peers which showed that the teacher is not the type of person who is directly close to having relationships with other people or have good social relations, but that does not mean it was bad, rather it was the standard way of approaching. The principal's opinion about the Islamic Education Teacher stated that the teacher is one of the good teachers in doing work. This interview revealed more about the Islamic Education teacher's behavior in interacting with other people and the teacher's colleagues. In addition, Equivalent here means that equality happens to someone both in terms of age, life or birth in the same era and era and in terms of the same profession such as teacher and teacher, not between teacher and student.

2. The other Islamic Education teachers, answering all the questions raised by researcher which can be concluded that: 1. The Islamic Education teacher were able to express feelings well, even doing something with pleasure. 2 . The teacher was able to express opinions in a friendly manner. 3 . The teacher admitted that have never been angry when teaching, it can happen because teacher did not bring outside problems when teaching. 4. The teacher respected students' opinions that differ from the beliefs and explanations explained at the time of teaching. 5. The teacher admitted that interacting with others quickly. In addition, this interview revealed more about how the teacher interact in teaching process, which were how the teacher interacting with students and a little revealing interactions outside of teaching.

3. Mrs. SM said that the Islamic Education teacher had almost perfect components of assertive behavior by the following conclusions that: 1.The 
teacher was able to express feelings well. 2. Expressing opinions and beliefs with only certain people such as those closest to personal matters. 3 . The teacher was able to express personal rights well. 4. Mrs. SR has seen that the PAI teacher is was in anger but not excessive anger rather felt angry in the standard way. 5. The teacher have good behavior, generous, often helpful, tolerant, responsible, easy to forgive, not selfish, but there are several factors that make the teacher sometimes forgot what the teacher has done in terms of teaching. This interview revealed more about the behavior of the teacher outside of teaching interactions in the form of interactions with peers.

4. Mrs. IS said that the Islamic Education teacher had almost perfect components of assertive behavior, by the following conclusions that: 1 . The Islamic Eduation teacher could express feelings well. 2. The teacher sometimes expressed beliefs and thoughts openly. 3. The teacher was able to express personal rights well. 4 . The teacher did not seem angry during the teaching process. 5. The teacher could interact with others quickly. 6 . The teacher is a good, honest, generous person. This interview revealed more about the behavior of the teacher outside of teaching interactions in the form of interactions with peers.

5. Mrs. MR said that the Islamic Education teacher had almost perfect components of assertive behavior, with the conclusion that: 1 . The teacher could express feelings well. 2. The teacher could express beliefs and thoughts openly. 3. The teacher was able to express personal rights well. 4 . The teacher did not seem to be angry during the subject-delivery. 5. The teacher was fast to interact with others. 6 . The teacher is a simple and tolerant kind of person. This interview revealed more about the teacher's behavior outside of teaching interactions in the form of interactions with peers.

6. Mrs.S said that the Islamic Education teacher had almost perfect components of assertive behavior, with the conclusion that: 1. The Islamic Education (IE) teacher can express feelings well. 2. The IE teacher was able to express beliefs and thoughts openly. 3. The IE teacher was able to express the personal rights of teachers well. 4. The IE teacher was spotted potentially being emotional at classroom, yet still calm and naturally delivered the subject. 5. The IE teacher is adaptable person who is fast to interact with others. 6 . The teacher is a good person, honest, merciful, and caring. But the IE teacher has the Dasein (dynamic \& active) behavior. This interview revealed more about teacher behavior outside of teaching interactions in the form of interactions with peers and in this interview, the researcher found and learned more about the behavior of the IE teacher due to the fact that Supriyati was a close friend of the IE teacher and known for the teacher for a long time.

7. According to interview results with 7 students of VIII D class which can be concluded that: 1 . Students enjoyed the learning pace of the Islamic Education (IE) teacher. 2. The IE teacher taught in fun and relaxed way as well as the teacher liked to tell jokes in the classroom for breaking the ice. 3.The IE teacher seemed never be angry in the classroom. 4. Final grades in Islamic Education Studies for students are good. This interview revealed more about the behavior teaching interaction that has been done by the IE teacher in the form of student-to-student interactions.

8. Based on interview results with 8 students of VII A class which can be concluded that|: 1 . Students were fond 
of learning Islamic Education Studies. 2. Students were excited with the way of teaching which the IE teacher applied. 3. According to students' description, the IE teacher have been angry for sometimes, but rather to advise the students, not in the form of anger which is considered as not appropriate. 4. The students' scores of the Islamic Education Studies which were taught by the IE teacher are relatively high. This interview revealed more about the behavior of the IE teacher in teaching interactions in the form of student-to-student interactions.

9. Interview results with 7 students of IX C class which can be concluded that: 1 . Students enjoyed the learning pace which was presented by the Islamic Education (IE) teacher. 2. But the students are not really fond of the IE teacher's teaching style 3 . The IE teacher was once spotted being angry in the classroom, but not angry in rough way, more to the firm or being discipline towards the students. 4 . The students' scores of the Islamic Education Studies which were taught by the IE teacher are relatively good. In addition, this interview revealed more about the behavior of the IE teacher in the classroom in the form of student-to-student interactions.

Specifically, according to all the interview results above, it can be seen how the Islamic Education (IE) teacher has the assertive behaviors, due to the interview questions that are taken from the components of assertive behavior with a variety of the same or almost different answers. Yet so far, the answers have consistency, and even if there are differences, the differences are not that significant. From the results of interviews conducted by researcher, it is expected that the application of assumptive behavior of the IE teachers can bring a good impact on improving student learning achievements of
Islamic Education Studies subject at Godean 1 Junior High School.

\section{B. Results of Assertive Behavior Implementation Applicated by Islamic Education Teacher in Improving Student Learning Achievement at SMPN 1 Godean.}

1. Results of Assertive Behavior The Components of Assertive Behavior

a) The ability to express feelings (for example to accept and express feelings of anger, warmth, and sexual behavior). From the results of research conducted through observation and interviews, the data obtained that the Islamic Education (IE) teacher was able to express the feelings well. The teacher was angry but not showing the excessive anger by shouting or throwing dirty words that are not appropriate, but he was angry with the appropriate and more firm. In the interview results, when the students are asked whether the teacher was ever angry or not, many people think that anger stated here is bad, but actually anger is not a bad thing, it is included in the ability to express our feelings, instead it needs to be asked to people who have never been angry because maybe they cannot express their feelings well since it does not rule out the possibility of us as ordinary people would have been angry and that is a natural emotion for human-beings. The possibility that people are never angry seems to be so they could cover their feeling so this is called as passive behavior where they are not honest with their true feelings.

b) The ability to express confidence and thinking openly (capable of expressing opinions, expressing disagreement and being assertive, although emotionally difficult to do so, even though we may have to sacrifice something). The Islamic Education teacher in this school were able to express their beliefs and thoughts openly but not always continuously 
which the IE teacher sometimes to do so when are needed. In an interview with the IE teacher directly, the teacher stated that does not speak the mind openly and honestly, as the teacher does not think we should and should not express our different beliefs and thoughts in the event of a disagreement or debate. Furthermore, the IE teacher probably did not want to upset the mood so being quiet is the choice. In contrast with the former fact, when the IE teacher was doing interview with close friends, the teacher was more open to them. It showed that the IE teacher does not express his thoughts and beliefs to anyone, only to certain people.

c) The ability to defend personal rights (not allowing others to interfere and use us). Based on the results of interviews with the Islamic Education (IE) teacher and other teachers, the IE teacher is able to defend the personal rights which one of the personal rights is being free to express the opinions. Among the existing rights are the right to freedom of movement, the right to freedom of expression, the right to freedom of choice and to be active in organizations, the right to freedom of choice, to embrace and practice religion, the right to work and a decent living for humanity. Thus, since it is talked about teacher, the right that can be explained here is the right to express an opinion which can be obtained from the results of the principal's interview that the IE teacher is able to express his personal rights by being able to express the opinion at the meeting.

d) The Impact of Assertive Behavior in Improving Student Learning Achievement at SMPN 1 Godean.

Based on the results of assertive behavior described above presenting the discussions about the impact on improving student learning achievement which has an objective to find out whether learning has been successful or can be said to be

outstanding or not, then it can be known through achievement tests that serve as a summative measure to determine final scores in a program, determining the level of mastery, or determining graduation (Djamarah, 2010: 304) as described in the following table:

The terms explanation:

- Miinimum Mastery Criteria (MMC) Score.

- Mid-Term Examination (MTE) Score

- Final-Term Examination (FTE) Score

Table 1. Students' Learning Achievementof VII Class

\begin{tabular}{|c|c|c|c|}
\hline Student's Name & Score of MMC & Score of MTE & Score of FTE \\
\hline Annisa & 76 & 86 & 92 \\
\hline Arini & 76 & 82 & 82 \\
\hline Arinto & 76 & 86 & 94 \\
\hline Aulia & 76 & 80 & 98 \\
\hline Bara & 76 & 80 & 86 \\
\hline Daniel & 76 & 78 & 90 \\
\hline Danis & 76 & 90 & 94 \\
\hline Diasifa & 76 & 76 & 80 \\
\hline Dimas & 76 & 90 & 90 \\
\hline Dwika & 76 & 84 & 92 \\
\hline Embun & 76 & 76 & 88 \\
\hline Fahmadia & 76 & 84 & 98 \\
\hline Fatma & 76 & 80 & 92 \\
\hline Fifi & 76 & 76 & 92 \\
\hline
\end{tabular}


Tarbiyah: Jurnal Ilmiah Kependidikan

Vol. 9 No. 1. January - June 2020 (1-11)

DOI: http://dx.doi.org/10.18592/tarbiyah.v9i1.3356

\begin{tabular}{|c|c|c|c|} 
Gayuh & 76 & 88 & 98 \\
\hline Ghina & 76 & 70 & 90 \\
\hline Gita & 76 & 84 & 86 \\
\hline Isniatul & 76 & 84 & 96 \\
\hline Kevin & 76 & 90 & 76 \\
\hline Luthf & 76 & 88 & 90 \\
\hline Moza & 76 & 90 & 86 \\
\hline M Afif & 76 & 74 & 96 \\
\hline M Rafii & 76 & 84 & 94 \\
\hline M Ridwan & 76 & 80 & 84 \\
\hline M Wibowo & 76 & 90 & 94 \\
\hline Nadia & 76 & 90 & 88 \\
\hline Nandana & 76 & 80 & 90 \\
\hline Rosyiana & 76 & 94 & 98 \\
\hline Safira & 76 & 70 & 90 \\
\hline Salma & 76 & 88 & 96 \\
\hline Sausan & 76 & 72 & 88 \\
\hline Widya & 76 & 90 & 92 \\
\hline
\end{tabular}

Table 2. Students' Learning Achievement of VIII Class

\begin{tabular}{|l|c|c|c|}
\hline \multicolumn{1}{|c|}{ Student's Name } & Scoore of MMC & Score of MTE & Score of FTE \\
\hline Ahmad Siddiq & 76 & 80 & 88 \\
\hline Aisha & 76 & 88 & 86 \\
\hline Aisyah & 76 & 82 & 84 \\
\hline Amira & 76 & 86 & 86 \\
\hline Anisa & 76 & 80 & 72 \\
\hline Annisa & 76 & 76 & 70 \\
\hline Arif & 76 & 80 & 88 \\
\hline Arifah & 76 & 84 & 74 \\
\hline Aziz & 76 & 84 & 70 \\
\hline Defita & 76 & 80 & 84 \\
\hline Desmont & 76 & 74 & 68 \\
\hline Dila & 76 & 84 & 84 \\
\hline Dina & 76 & 66 & 82 \\
\hline Dwi & 76 & 80 & 90 \\
\hline Dwi & 76 & 82 & 82 \\
\hline Fahmi & 76 & 84 & 82 \\
\hline Faiq & 76 & 86 & 84 \\
\hline Ferri & 76 & 74 & 64 \\
\hline Ficking & 76 & 80 & 82 \\
\hline Hamim & 76 & 78 & 74 \\
\hline Hasna & 76 & 84 & 92 \\
\hline Laila & 76 & 82 & 88 \\
\hline Muhamad & 76 & 84 & 82 \\
\hline Naila & 76 & 80 & 88 \\
\hline Nawang & 76 & 80 & 80 \\
\hline Norma & 76 & 84 & 92 \\
\hline Novia & 76 & 84 & 86 \\
\hline Novita & & 80 & 86 \\
\hline & & \\
\hline
\end{tabular}


Tarbiyah: Jurnal Ilmiah Kependidikan

Vol. 9 No. 1. January - June 2020 (1-11)

DOI: http://dx.doi.org/10.18592/tarbiyah.v9i1.3356

\begin{tabular}{|l|l|l|l|} 
Nurul & 76 & 88 & 90 \\
\hline Rikhan & 76 & 84 & 76 \\
\hline Salsabila & 76 & 82 & 90 \\
\hline Silvia & 76 & 78 & 74 \\
\hline
\end{tabular}

Table 3. Students' Learning Achievement of IX Class

\begin{tabular}{|c|c|c|c|}
\hline Student's Name & Score of MMC & Score of MTE & Score pf FTE \\
\hline Abimanyu & 80 & 76 & 98 \\
\hline Ahmad & 80 & 80 & 96 \\
\hline Azki & 80 & 84 & 92 \\
\hline Bagas & 80 & 74 & 90 \\
\hline Chyndi & 80 & 82 & 90 \\
\hline Danisya & 80 & 78 & 94 \\
\hline Elvina & 80 & 80 & 92 \\
\hline Fara & 80 & 78 & 92 \\
\hline Faridah & 80 & 84 & 96 \\
\hline Firlita & 80 & 82 & 96 \\
\hline Fitri & 80 & 76 & 96 \\
\hline Ginggar & 80 & 82 & 94 \\
\hline Harits & 80 & 80 & 94 \\
\hline Hasna & 80 & 80 & 98 \\
\hline Inda & 80 & 80 & 88 \\
\hline Isnaini & 80 & 78 & 86 \\
\hline Latifa & 80 & 80 & 94 \\
\hline Mahfudh & 80 & 84 & 96 \\
\hline Meutia & 80 & 82 & 96 \\
\hline Mufti & 80 & 78 & 94 \\
\hline Muhammad & 80 & 82 & 88 \\
\hline Najla & 80 & 82 & 98 \\
\hline Nur & 80 & 82 & 88 \\
\hline Nurmaza & 80 & 82 & 96 \\
\hline Nurul & 80 & 86 & 96 \\
\hline Oktafianto & 80 & 88 & 92 \\
\hline Rahadyan & 80 & 82 & 94 \\
\hline Restu & 80 & 82 & 94 \\
\hline Rizka & 80 & 78 & 92 \\
\hline Salma & 80 & 84 & 96 \\
\hline Satria & 80 & 82 & 98 \\
\hline Yazid & 80 & 86 & 94 \\
\hline
\end{tabular}


Hadari Nawawi argues that learning achievement is the level of student achievement expressed in the form of scores that will be obtained from the test results regarding the number of specific subject matters (Nawawi, 1999: 15). According to the data in the table above, it can be seen that student achievement has a good impact with an average score above the Mastery Minimum Criteria (MMC) and further increases in the results of Mid-Term Examination. Above all, this means that the students' achievement scores will always increase through a number of behaviors implemented by the Islamic Education (IE) teacher. In particular, being able to express feelings well, sometimes expressing thoughts and beliefs, as well as being able to defend personal rights. Furthermore, the factors that influence learning outcomes are internal and external factors, but the researcher can only describe the external factors since only those that can be observed during the study, to illustrate: a) Social factors, which means the family environment, school environment, community environment and group environment. b) Cultural factors, such as customs, science, technology and art. c) Physical environmental factors, such as home and study facilities. d) Spiritual or religious environmental factors (Usman \& lilis, 1993: 10). With reference to these factors, the school environment is mainly influential, what is more, the classroom environment is the closest environment to the students and where there is very much dominated by the teacher.

As a result, the role of the teacher greatly influences the success of student learning achievement, although it is not only the behavior of the teacher that influences student learning outcomes in achieving an achievement or good grades, it is undeniable that the teacher's behavior greatly influences the learning process. To illustrate, how can students receive lessons well with teachers they are not fond of or the teachers who behave rudely or cruelly throughout the learning process so the lesson will only make fear and anxiety to students. It is proved from the data above, the students' grades always increase stemming from the results of observations and interviews with students which most of them were enjoyed learning Islamic Education Studies turned out that they feel delightful and like to learn the subject with the aforementioned-Islamic Education (IE) teacher.

\section{CLOSURE}

The particular Islamic Education (IE) teacher's assertive behaviors are able to express feelings well, express thoughts and beliefs openly, and defend personal rights. Among the components of assertive behavior, they have been owned by the IE teacher, but not all components are perfectly owned by the teacher. Equally, bearing in mind that there is such perfect human being and neither is the teacher. Moreover, not only components, the characteristics of assertive behavior are also a reference of the application of assertive behaviors that are actually not much different from the components of assertive behavior, however the characteristics of assertive behavior are more profound such as "Feel free to express emotions felt through words and actions. For instance, being able to communicate with others, such as strangers, friends and family. Particularly, having an active view of life. and act in a way that the teacher respects himself. Then, of the 3 components and 4 characteristics of assertive behavior, the teacher applied 2 components and 3 characteristics of assertive behavior.

Thus, based on some assertive behaviors that have been implemented by the IE teacher, students are happier and more enthusiastic in learning the subject of Islamic Education Studies which eventually this has an effect on student achievement, as evidenced by the midterm and final test scores of students increasing higher by having average scores above the Mastery Minimum Criteria (MMC). 


\section{REFERENCES}

Abidin, Syahrul, "Strategi Komunikasi Guru dalam Meningktkan Prestasi Belajar", dalam Jurnal Ihayul Arabiyah Fakultas Ilmu Sosial UIN Sumatera Utara Medan, vol. 3 No. 2 (Desember, 2017), hal. 116.

Alberti, Robert \& Michael Emmons, Your Perfect Right (Hidup lebih bahagia dengan mengungkapkan hak), Jakarta: PT Elex Media Komputindo, 2002.

Djamarah, Syaiful Bahri, Guru dan Anak Didik dalam Interaksi Edukatif, Jakarta: Rineka Cipta, 2010.

Fathurrohman, dkk., Guru Profesional, Bandung: PT Refika Aditama, 2012.

Fensterheim, Harbert \& Jean Bear, Jangan Bilang Ya Bila Anda Akan Mengatakan Tidak, Jakarta: Gunung Jati, 1995.

Goleman, Daniel, Kecerdasan Emosional, Jakarta: Gramedia Pustaka Utama, 2007.

H. B. Sutopo, Pengantar Penelitian Kualitatif: Dasar-dasar Teori Praktis, Jakarta: Rineka UNS Pers, 1998.

Hamzah B. Uno, Orientasi Baru Dalam Psikologi Pembelajaran, Jakarta: PT. Bumi Aksara, 2006.

Helmawati, Pendidik sebagai Model, Bandung: PT Remaja Rosdakarya, 2016.

Mathew B. \& A. Michael Hiberman, Analisis Data Kualitatif, Penerjemah: Tjetjep Rohidi Rohindi, Jakarta: UI press, 1992.

Moleong, Lexi J., Metode Penelitian Kualitatif, Bandung: PT Remaja Rosdakarya, 2007. Milles,

Nawawi, Hadari, Administrasi Pendidikan, Jakarta: CV. Mas Agung, 1999

Selfi, "Penerapan Teknik Assertive Training dalam Mereduksi Konformitas Negatif Terhadap Kelompok Sebaya di SMP”, dalam Journal of Educational Science and Technology Pascasarjana
Universitas Negeri Makassar, vol. 3 No. 2 (Agustus, 2017), hal. 153.

Sugiyono, Metode Penelitian Pendidikan Pendekatan Kuantitatif, Kualitatif, dan R\&D, Bandung: Alfabeta, 2015.

Suharismi Arikunto, Prosedur Penelitian Suatu Pendekatan Praktis, Jakarta: Rineka Cipta, 2012.

Usman, Moh. Uzer dan Lilis Setiawati, Upaya Optialisasi Kegiatan Belajar Mengajar, Bandung: Remaja Rosdakarya, 1993. 